Robey, J. M., Blyth, C. S. and Mueller, F. O., 1971 "Athletic injuries. Application of epidemiologic methods". JAMA 217: 184-189.

Sperryn, P. N. and Williams, J. G. P., 1975 'Why sports injury clinics?” Brit.Med.J. 5966: 364-365.

Schwerdtner, H. P. and Schobert, H., 1973 "Die Spondylolyse im Hochleistungssport bei Geräteturnerinnen". Z. Orthop. 111: 934-940.

Tütsch, C. and Ulrich, S. P., 1974 "Wirbelsäule und Hochleistungsturnen bei Mädchen". Schweiz.Rundschau Med. (Praxis) 63: 946-949.

Williams, J. G. P. and Sperryn, P. N., 1976. Sports Medicine, 2nd Edition, Edward Arnold Ltd., London.

Williams, J. G. P. and Sperryn, P. N., 1972 “Overuse injury in sport and work". Brit.J.Sports Med. 6: 50-51.

Vuori, I., Aho, A. J. and Karakorpi, T., 1972 “Sports injuries”. Duodecim 88: 700-711.

\title{
OBITUARY
}

\section{Mrs. Thelma Puddifoot, MCSP, SRP}

Thelma Puddifoot, a very dedicated physiotherapist in private practice in Kingston Vale, London, died on September 28th after two years of fighting against impossible odds. Her very many friends, colleagues, and patients, already miss her deeply, but people like Thelma have a long lasting influence. For thirteen years, following the death of her husband, she had built up her practice and educated her two boys, giving the best of herself to patients and family. Over these years there were many sports men and women, including some of top rank, who had reason to be very grateful to Thelma, she well understood that a physiotherapist's greatest asset is her hands, and she used them with exceptional intelligence.

She joined the British Association of Sport and Medicine in 1977, and was also a member of the Association of Chartered Physiotherapists in Sports Medicine, taking part in the residential conference held at the University of Sussex in 1977.

A Physiotherapy Department at the New Victoria Hospital, where she had worked for many years, is to be set up and named after her.

Pam Woods 